\title{
Modelling gas supply systems with a high role of autonomous consumers (the case of Mongolia)
}

\author{
Darya Maksakova ${ }^{1, *}$, and Sergei Popov ${ }^{1}$ \\ ${ }^{1}$ Melentiev Energy Systems Institute of Siberian Branch of the Russian Academy of Sciences, Department of Complex and Regional \\ Problems in Energy, 664033130 Lermontov St., Irkutsk, Russia
}

\begin{abstract}
The paper presents a tool to optimize gas infrastructure systems and analyses some aspects of modelling related to autonomous gas consumers. A model of national gas infrastructure creation in Mongolia is proposed. The model is linked with the model of the regional Northeast Asian gas market and the financial models of gas infrastructure facilities. The model determines the optimal design of the national gas infrastructure system, i.e. the number of the facilities, their capacities, locations and the transport modes for connecting the consumption centres. The role of autonomous consumers is considered by introducing the demand for liquefied natural gas separately from the demand for pipeline gas. The scope of the model application is demonstrated by an illustrative example. The results show the rational natural gas import and distribution patterns. The need for expanding the energy cooperation between Mongolia and the other Northeast Asian countries to create gas industry in Mongolia is highlighted.
\end{abstract}

Keywords. Mongolia, Northeast Asia, gas supply infrastructure, modelling.

\section{Introduction}

Mongolia has rich coal, crude oil, solar and wind energy resources. In the cities, Combined Heat and Power Plants (CHPPs) fuelled by coal represent the basis of the energy supply systems. About a half of the county population resides in the capital city Ulaanbaatar. It is worth noting that more than 60 percent of Ulaanbaatar's population lives in traditional Mongolian houses (gers) equipped with stoves, which burn coal and are harmful to the environment [1]. The high air pollution level raise the problem of coal-to-gas switching in the energy production and petroleum-to-gas switching in the transport sector, including railways and special purpose vehicles in mining. Besides, mobile gers in agriculture can contribute to the demand for gas.

The country has no conventional gas resources, while there are significant coal-bed methane resources estimated at 3.2 trillion cubic meters [2]. Nevertheless, in spite of technical feasibility, high costs and capital investments, water supply issues and the lack of gas supply infrastructure are the barriers for the large-scale exploration and production of natural gas in Mongolia.

The issue of gas supply to Mongolia has been discussed for a long time since the end of the XX century. In 1998 Melentiev Energy Systems Institute carried out the research "The concept for development of the oil and gas industry in eastern regions of Russia and study on the possibility to export hydrocarbon resources to the APR countries" $[3,4]$. According to the concept, the gas pipeline "Irkutsk-Ulaanbaatar-Beijing" ought to have become a part of the unified gas supply system in the eastern regions of Russia. The pipeline has been discussed at the sessions of the Northeast Asian Natural Gas \& Pipeline Forum (NAGPF). As a result of the researches conducted by the NAGPF, the demand for gas in Mongolia was estimated and the institutional and infrastructural requirements were indicated. Finally, the pipeline was included in "A Long-Term Vision of Natural Gas Infrastructure in Northeast Asia" [5].

The gas pipeline from Russia to China across Mongolia was discussed at the Shanghai Cooperation Organisation summits in 2018 [6,7] and 2019 [8] and at the Eastern Economic Forum in 2019 [9]. In September 2019 the President of Russia gave the assignment to the stateowned gas company Gazprom to analyse the opportunities to use the gas resources of Irkutsk Region, Krasnoyarsk Territory and the Yamal Peninsula for gas supplies to China across Mongolia [10]. In August 2020 Gazprom and the Government of Mongolia agreed to set up a special-purpose company for conducting a feasibility study for the construction and operation of the pipeline [11].

In 2018 by starting LNG (liquefied natural gas) imports from China and later in 2019 from Russia, the country made its first steps on the way to the gas industry creation. The construction of the gas pipeline from Russia to China passing Mongolia's territory "Irkutsk-UlaanbaatarBeijing" is to form the basis to meet total country's demand for gas and expand Mongolia's opportunities to participate in the regional Northeast Asian energy cooperation initiatives. Currently, the energy cooperation of Mongolia with the other countries of Northeast Asia (NEA) is limited to export of coal and crude oil, import of petroleum products, liquefied petroleum gases (LPG)

* Corresponding author: maksakova@isem.irk.ru 
and a small amount of LNG, and electricity trade with the only neighbours Russia and China.

The structure of energy export of Mongolia to NEA is represented in Table 1. China is a major export market for Mongolia's coal resources and a sole importer of Mongolia's crude oil. Besides, China provides transit services for Mongolian coal.

Table 1. Energy export of Mongolia to the other NEA countries in 2019, million US dollars.

\begin{tabular}{|c|c|c|c|c|}
\hline Importer & Coal & Crude oil & Electricity & $\begin{array}{c}\text { Total } \\
\text { energy } \\
\text { export }\end{array}$ \\
\hline China & 3073 & 306 & - & 3379 \\
\hline Russia & $\dagger$ & - & $\dagger$ & $\dagger$ \\
\hline $\begin{array}{c}\text { Republic of } \\
\text { Korea }\end{array}$ & $\dagger$ & - & - & $\dagger$ \\
\hline \begin{tabular}{c} 
Total world \\
\hline
\end{tabular} & 3073 & 306 & $\dagger$ & 3379 \\
\hline
\end{tabular}

$\dagger$ Less than 0.5 .

Source: [12].

As Table 2 shows, almost all of the energy import comes to Mongolia from NEA. Russia is the major supplier of petroleum products and China provides most of the electricity import.

Mongolia plans to launch its first refinery with the capacity of 1.5 million tonnes of crude oil per year in 2022 [13]. Thus, the trade flows will be reshaped, as Mongolia will be able to stop petroleum products (including LPG) imports.

Table 2. Energy import of Mongolia from the other NEA countries in 2019, million US dollars.

\begin{tabular}{|c|c|c|c|c|c|}
\hline Exporter & $\begin{array}{c}\text { Petroleum } \\
\text { products }\end{array}$ & Electricity & LPG & LNG & $\begin{array}{c}\text { Total } \\
\text { energy } \\
\text { import }\end{array}$ \\
\hline Russia & 1065 & 28 & 14 & $\dagger$ & 1107 \\
\hline China & 53 & 118 & - & $\dagger$ & 171 \\
\hline $\begin{array}{c}\text { Republic } \\
\text { of Korea }\end{array}$ & 24 & - & 3 & - & 26 \\
\hline Japan & 2 & - & - & - & 2 \\
\hline $\begin{array}{c}\text { Total } \\
\text { world }\end{array}$ & 1164 & 145 & 16 & $\dagger$ & 1325 \\
\hline
\end{tabular}

$\dagger$ Less than 0.5 .

Source: [12].

Russia and China are the key Mongolia's trade partners. Moreover, the existent experience of energy trade and cooperation can be expanded further to exploit the advantages of bordering with Russia owning highly competitive and abundant gas reserves and China being expected to become the driver of the global gas market.

The aim of the paper is to propose a modelling framework to research the national gas supply system creation opportunities in Mongolia and to provide an illustrative example showing the opportunities of the described tools.

The objectives include:

- analysing the opportunities and limits of the existent model of Gas Infrastructure Development in the East Asian Region (GEAR),

- highlighting the special characteristics of the future gas infrastructure in Mongolia,

- formulating a model of the national gas infrastructure system of Mongolia interacting with the GEAR model,

- running an illustrative scenario to demonstrate the model opportunities and identify the areas for improvement.

\section{Modelling tools}

Mongolia's participation in the regional Northeast Asian gas market can be analysed by employing the GEAR model. The GEAR model is a linear programming problem that minimizes total costs to satisfy the demand for imported gas in China, Japan, the Republic of Korea and Mongolia subject to balance and infrastructure constraints [14].

It is a static model, i.e. it describes the Northeast Asian gas market for a specific year. The main inputs are gas production, pipeline transportation, marine and railway LNG transportation, liquefaction and regasification costs and aggregated demand for gas in the gas consumption centres (nodes).

The production and transportation optimisation problem GEAR allows identifying the most competitive gas suppliers and gas supply routes, estimating gas transportation volumes for the each route as well as the rent revenues, which are the difference between the dual (shadow) prices in the nodes and costs to supply gas to the nodes.

The GEAR model analyses the different scenarios to supply Mongolia with gas, namely, LNG import from Russia or China and the construction of the gas pipeline "Irkutsk-Ulaanbaatar-Beijing". The demand for gas is aggregated in Ulaanbaatar.

Analysing the role of Mongolia in the regional gas market described by the GEAR model is the first stage of the study. This model allows estimating the competitiveness of the supply sources and routes subject to limited capacities and provides with gas import costs estimations.

However, due to the fact that the country's demand is aggregated only in the single node, the necessity to build the national gas infrastructure, which would be different in the different import scenarios, is not taken into account.

That is why a special model of the national gas infrastructure creation is developed for Mongolia. The model considers the optimal directions of LNG or pipeline gas import and the construction of gas infrastructure facilities to satisfy the demand across the entire territory 
of Mongolia. The infrastructure facilities comprise pipelines, vehicles with a cryogenic cistern for LNG transportation, liquefaction plants and regasification facilities.

The GEAR model supplies the model of the national gas infrastructure with such parameters as import costs and maximum import volumes. Such a linkage between the models allows estimating the impact of the Northeast Asian gas market frameworks on the national gas supply system design.

Every infrastructure facility type is described by a financial model. The financial models evaluate the cumulative discounted cash outflows from operations and investing activities. These outflows are to be the objective function coefficients of the national gas infrastructure model.

The financial models of the gas infrastructure facilities investment projects can also be used to analyse the opportunities for increasing the competitiveness of the gas supply options and improving the performance indicators of the facilities.

The financial models calculate the main financial indicators from sales to net income and return ratios. These models estimate the minimum price, or tariff, to ensure the equivalence of the cumulative discounted revenues and the cumulative discounted cash outflows from operations and investing activities.

The financial models interact with the model of the national gas supply system of Mongolia. Firstly, the cash outflows from operations and investing activities are the main input parameters in the model of the national gas supply system of Mongolia. Secondly, the capacities of the gas infrastructure facilities are chosen taking into account gas demand profiles for typical consumers.

On the one hand, the interaction between the financial models and the model of gas supply system allows identifying the financial and performance parameters that are necessary to achieve a certain level of the competitiveness. On the other hand, it allows identifying the competitiveness level when the financial and performance parameters are given.

\section{The model of gas supply infrastructure in Mongolia}

Mathematically, the model of national gas supply infrastructure is a mixed integer linear problem.

The integer variables are the number of constructed infrastructure facilities and the number of infrastructure facilities at the beginning and at the end of the modelling interval (projected time period). The infrastructure facilities are gas pipelines between the nodes, LNG vehicles delivering LNG from one node to another, regasification and liquefaction facilities in the nodes.

The non-negative variables are the volumes of pipeline gas and LNG transported between the nodes and the regasification, liquefaction and import volumes in the nodes during the last year of the modelling interval.

The objective is to minimize the cumulative discounted cash outflows from investment and operating activities to create and operate gas infrastructure and to import LNG and pipeline gas during the modelling interval.

The model has three types of the constraints:

1) balance constraints,

2) capacity constraints,

3) existing infrastructure constraints.

The balance constraints are calculated for pipeline gas and LNG separately. They ensure that the sum of net inflow of gas to the node from the other nodes, net inflow from transformation processes and import is equal to the demand for gas in the node during the last year of the modelling interval.

The transformation processes are regasification and liquefaction. Regasification adds the volume of pipeline gas in the node and liquefaction reduces the volume of pipeline gas in the node. And vice versa, liquefaction adds the volume of LNG in the node and regasification reduces the volume of LNG in the node.

Transportation, regasification and liquefaction losses as well as facilities' own energy consumption are accounted for in the balance constraints.

In this version of the model, import of pipeline gas is possible only along the pipeline "Irkutsk-UlaanbaatarBeijing" and LNG import is possible only along the Trans-Mongolian Railway.

The capacity constraints ensure that the volumes of pipeline gas and LNG transported between the nodes, liquefaction and regasification volumes in the nodes do not exceed the total capacities of the corresponding gas infrastructure facilities. The cumulative capacities are calculated based on the quantity of the facilities and their capacities.

Existing infrastructure constraints link the number of the existing infrastructure facilities at the beginning of the modelling interval with the number of the facilities at the end of the modelling interval.

It is assumed that there is no infrastructure at the beginning of the first period. Decommission is not considered in this version of the model as the useful lifetime of the gas infrastructure facilities exceeds the period within the modelling interval when gas demand exists (2025-2040).

\section{Demand projections}

We use a two-stage approach when making energy demand projections for NEA. Firstly, we project the scales and structure of final energy consumption to satisfy the demand for useful energy. Secondly, we project energy transformation and energy carriers international transportation volumes to estimate total primary energy consumption.

When estimating final energy consumption projections, the following assumptions are used:

- estimations of the future social and economic development,

- cost-performance parameters for the different energy technologies included in the projections,

- the difference in energy carriers prices.

In the model of national gas supply system of Mongolia, gas demand at the end of period is aggregated in the 25 
nodes. Natural gas flows in and out the nodes. Besides, regasification and liquefaction processes take place in the nodes.

Pipeline gas demand and LNG demand are accounted for separately, with LNG demand representing the demand from transport sector and autonomous consumers. Thus, it is assumed that natural gas is transported from the node to its autonomous final consumers, whose demand is aggregated, only in a liquid state due to long distances and low consumption volumes. At the same time, pipeline transport can be used between the nodes.

In the illustrative example provided in this paper, we assume total country's annual demand for gas during the period 2025-2040 at 6.6 billion cubic meters (the socalled "high gas" case), with the demand for pipeline gas accounting for 3.7 billion cubic meters.

\section{Capacity of the infrastructure facilities}

The infrastructure facilities vary by their capacity types. In this version of the model, we consider three types of pipeline capacities, two types of LNG vehicles capacities, which correspond to the volumes of cryogenic cisterns, two types of regasification facilities and four types of liquefaction facilities (Table 3).

Table 3. Capacity types.

\begin{tabular}{|c|c|c|}
\hline $\begin{array}{c}\text { Infrastructure } \\
\text { facility }\end{array}$ & Capacity type & Unit \\
\hline Pipelines & $\{0.4 ; 0.6 ; 1\}$ & $\begin{array}{c}\text { billion cubic meters } \\
\text { per year }\end{array}$ \\
\hline LNG vehicles & $\{15 ; 40\}$ & $\begin{array}{c}\text { cubic meters per } \\
\text { truck/cistern }\end{array}$ \\
\hline $\begin{array}{c}\text { Regasification } \\
\text { facilities }\end{array}$ & $\{8 ; 17\}$ & $\begin{array}{c}\text { million cubic } \\
\text { meters per year }\end{array}$ \\
\hline $\begin{array}{c}\text { Liquefaction } \\
\text { facilities }\end{array}$ & $\{0.1 ; 0.5 ; 1.5 ; 2.5\}$ & $\begin{array}{c}\text { million tons of } \\
\text { LNG per year }\end{array}$ \\
\hline
\end{tabular}

It is important to note that including or excluding the capacity types is an iterative process. If the modelling results show that in the node or on the route, a large number of infrastructure facilities with maximum capacity are used or the facilities with minimum capacity are underused, new capacity types should be added to ensure more rational results. And vice versa, the unused capacities can be excluded to reduce the computational time.

\section{Infrastructure facilities costs}

The financial models of gas infrastructure facilities calculate the following types of cash outflows:

- cash outflows related to constriction investments,

- cash outflows related to maintenance investments,

- cash outflows from operations.

The cash outflows related to construction investments take place before commissioning the infrastructure facilities. It is assumed that the infrastructure should be commissioned at the beginning of the year 2025, i.e. actually, a static version of the model is described. These investments consist in the investments in the capital equipment, ancillary equipment and buildings as well as design, engineering and project management costs.

The maintenance investments take place when the useful life of the assets is less than the modelling interval of the national gas supply system model. In this case, new equipment should be commissioned in order to substitute the equipment that has been depreciated.

The cash outflows from operations consider personnel costs, maintenance services costs, consumables costs and taxes. They do not comprise the costs related to the energy losses and own energy facilities' consumption because these costs are accounted for in the national gas supply infrastructure model, i.e. in the financial models, variable operating costs are not included.

In this version of the model, the cash outflows for regasification and liquefaction facilities and for LNG vehicles do not vary with the nodes and routes, correspondingly. At the same time, the investments in pipeline construction per $\mathrm{km}$ are different for the each route, as some expert assessments of local geography and climate are taken into account.

Table 4 demonstrates the energy services tariffs, which would be set by the infrastructure facilities, that ensure the equality between the cumulative discounted cash inflows from sales and the cumulative discounted cash outflows during the modelling interval 2021-2040. In other words, the Net Present Value achieved at these tariffs is equal to zero.

All cash flows are real, i.e. net of inflation. The real discount rate is set at 9 percent.

These tariffs do not take into account the energy losses and own consumption components. Besides, it is assumed that the infrastructure facilities work at full capacity. Thus, the real tariffs should be higher.

Pipeline tariffs depend on the distance, diameter and local geography and climate. The other tariffs depend on infrastructure capacities, as the location factor is not considered. The higher the capacities, the lower the tariffs.

Table 4. Energy services tariffs.

\begin{tabular}{|c|c|c|}
\hline $\begin{array}{c}\text { Infrastructure } \\
\text { facility }\end{array}$ & Tariff & Unit \\
\hline Pipelines & $9-17$ & $\begin{array}{c}2020 \text { US\$ per } 1000 \text { cubic } \\
\text { meters per 100km }\end{array}$ \\
\hline LNG vehicles & $8-20$ & $\begin{array}{c}2020 \text { US\$ per tonne of LNG } \\
\text { per } 100 \mathrm{~km}\end{array}$ \\
\hline $\begin{array}{c}\text { Regasification } \\
\text { facilities }\end{array}$ & $16-35$ & $\begin{array}{c}2020 \text { US\$ per } 1000 \text { cubic } \\
\text { meters }\end{array}$ \\
\hline $\begin{array}{c}\text { Liquefaction } \\
\text { facilities }\end{array}$ & $175-202$ & 2020 US\$ per tonne of LNG \\
\hline
\end{tabular}




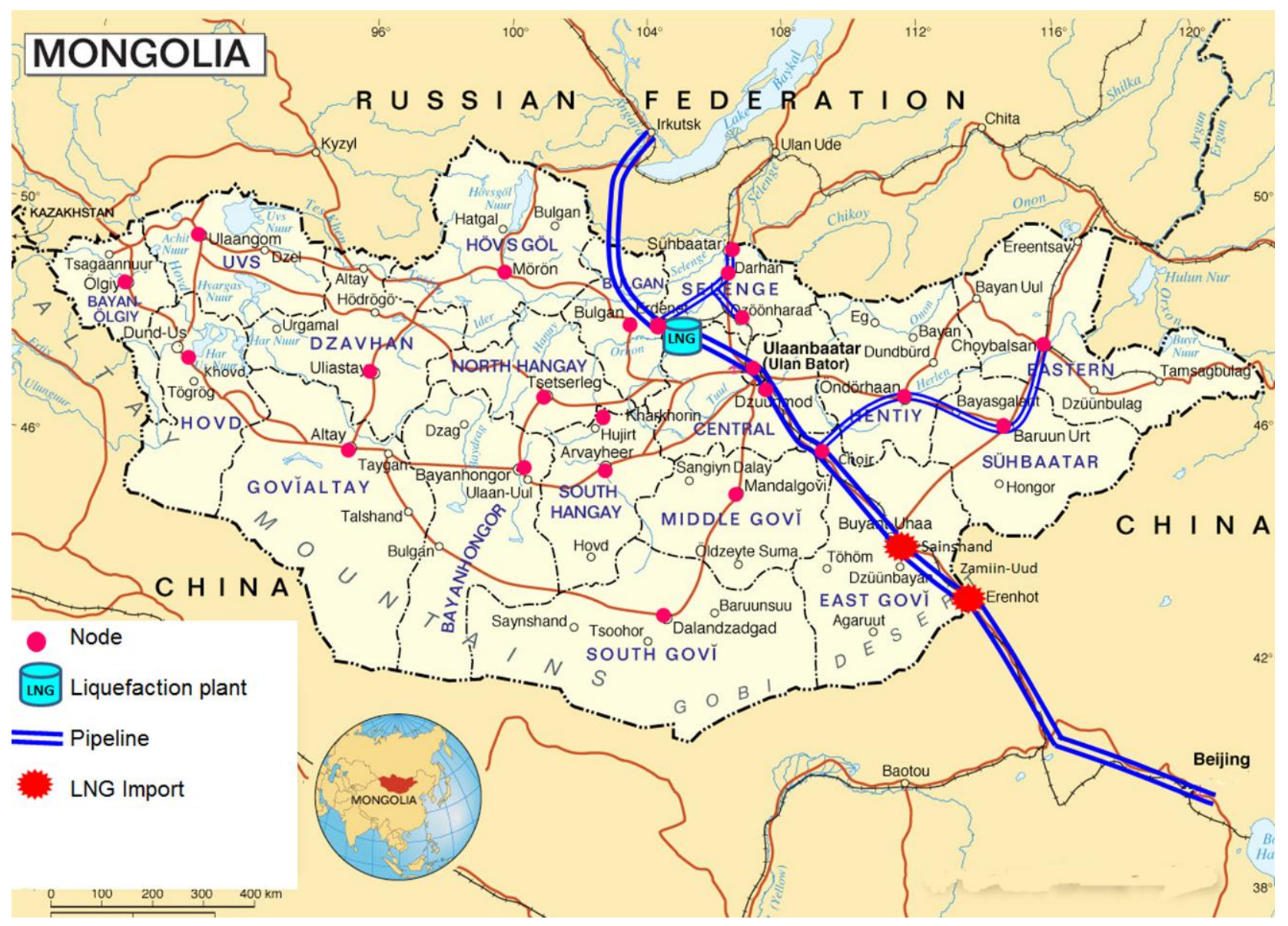

Fig. 1. Modelling results.

\section{Modelling results}

Figure 1 demonstrates the results of illustrative modelling. It is important to note that this illustrative example does not consider the stages of gas infrastructure creation. This means that the results would be different if the model considered that the consumers were connected to the infrastructure stage-by-stage. In other words, it would probably be better to build several infrastructure facilities with smaller capacities during the different periods than to build one facility with bigger capacity because the facility was being underused while the costs were being incurred.

The modelling results indicate that

1) An optimal solution is to build a mid-scale liquefaction plant with the capacity of 2.5 million tons of LNG per year in Erdenet. The feed gas is to come from the gas pipeline "Irkutsk-Ulaanbaatar-Beijing".

2) A very small amount of LNG ( 0.5 percent of the imported gas) is to be imported in the border areas by rail transport.

3) The construction of the branches from the gas pipeline "Irkutsk-Ulaanbaatar-Beijing" is possible in some areas in the eastern parts of the country, while LNG supply is more feasible in the western parts.

\section{Conclusions}

Mongolia can play an important role in the process of the Northeast Asian gas market development. The participation of the country will ensure not only cost reduction effect when transporting gas from China to Russia but also the environment for the creation of the country's own gas industry contributing to sustainable economic, social and environmental development.

The proposed modelling tools can be used to estimate the role of national gas consumption patterns and the niches of pipeline gas and LNG exporters when developing national gas supply systems.

The development of the modelling tools should be directed to take into account the stages of gas infrastructure development and the demand dynamics.

The model of the national gas supply system will be expanded to include an optimal schedule of infrastructure facilities commissioning. This schedule could reflect long-term energy strategy goals and thereby support decision-making process.

The study was supported by RFBR research project 18-51094006. The authors would like to thank AIMMS company for providing the free software for academic purposes that allowed them to make the computations. 


\section{References}

1. Air pollution in Mongolia. Bulletin of the World Health Organization, 97, 79-80 (2019) DOI: http://dx.doi.org/10.2471/BLT.19.020219

2. C. Otgochuluu, R. Bold-Erdene, ERINA Rep., 127, 20-24

Available: https://www.erina.or.jp/en/wpcontent/uploads/2015/02/se12716_tssc.pdf

3. B. G. Saneev, L. A. Platonov, A. D. Sokolov et al., The $6^{\text {th }}$ International Conference on Northeast Asian Natural Gas Pipeline: Multilateral Cooperation (2000)

4. The development of oil and gas industry in the east of Russia in Voropai N. I. (Ed.) Energy of the XXI century: energy systems and management (Nauka, Novosibirsk, 2004) Available: http://isem.irk.ru/upload/iblock/36a/36a8101dcbf57 b52aa6f964f3c7832cb.pdf

5. A Long-Term Vision of Natural Gas Infrastructure in Northeast Asia, 2009 version. Available: http://www.nagpf.info/research/5research.htm

6. Meeting with Chinese President Xi Jinping and Mongolian President Khaltmaagiin Battulga. June 9, $2018 . \quad$ Available: http://en.kremlin.ru/events/president/news/57713

7. Meeting with President of Mongolia Khaltmaagiin Battulga. June 9, 2018. Available: http://en.kremlin.ru/events/president/news/57711

8. Meeting with President of China Xi Jinping and President of Mongolia Khaltmaagiin Battulga. June 14, 2019.2 Available: http://en.kremlin.ru/catalog/countries/MN/events/60 753

9. Plenary session of the Eastern Economic Forum. September 5, 2019. Available: http://en.kremlin.ru/events/president/news/61451

10. Meeting with Gazprom CEO Alexei Miller. September $\quad 9, \quad 2019 . \quad$ Available: http://en.kremlin.ru/events/president/news/61486

11. Gazprom and Mongolian Government sign Memorandum of Intent. August 25, 2020. Available: https://www.gazprom.com/press/news/2020/august/ article511605/

12. Trade Map. Trade statistics for international business development. Available: https://www.trademap.org/

13. Mongolia breaks ground on country's first refinery. Oil \& Gas Journal. Available: https://www.ogj.com/refiningprocessing/refining/optimization/article/17296633/ mongolia-breaks-ground-on-countrys-first-refinery

14. S. P. Popov, D. V. Maksakova, E3S Web of Conferences 114, $02004 \quad$ (2019) DOI: https://doi.org/10.1051/e3sconf/201911402004 